\title{
STUDI PEMASARAN JASA PENDIDIKAN: FAKTOR-FAKTOR YANG MEMENGARUHI MAHASISWA MEMILIH PROGRAM STUDI BARU
}

\author{
Ismaulina \\ Institut Agama Islam Negeri Lhokseumawe \\ ismaulina@gmail.com \\ Ali Muhayatsyah \\ Institut Agama Islam Negeri Lhokseumawe \\ muhayatsyah@gmail.com \\ Suryani \\ Institut Agama Islam Negeri Lhokseumawe \\ suryapijar@yahoo.com \\ Putri Sri Anita \\ Institut Agama Islam Negeri Lhokseumawe \\ putriput336@gmail.com
}

Abstract

Instititut Agama Islam Negeri (IAIN) Lhokseumawe is the only Islamic education campus in Lhokseumawe city, which one of its faculties is the Faculty of Islamic Economics and Business, consisting of Sharia banking and Sharia Accounting study programs. This research tries to determine factors influencing the students' decision to choose the new study program in the Faculty of Islamic Economics and Business, IAIN Lhokseumawe. This research used analysis factor methods using SPSS. The study samples are Sharia banking and Sharia Accounting students. The research results explained that the investigated two-factor groups: the first-factor group includes the place, process, physical evidence, price, product, decision, and economy. The second-factor group includes positive issues and promotion. The positive issue factor is the highest and dominated the students' decision to choose the study programs. The following factors included place, process, physical evidence, price, product, promotion, decision, and economy. Thus, there is no difference between factor 1 and factor 2 variables influencing the students' decision when choosing the departments. This research is limited to two study programs in an Islamic higher education institution. Future research can involve students' parents and compare with other study programs using other research methods to get a complete picture to deepen the factors influencing students to choose a new study program.

Keywords: decision making; marketing for educational services; new department; sharia accounting; sharia banking.

\section{PENDAHULUAN}

Mahasiswa dan calon mahasiswa semakin pintar, sadar, dan kritis terhadap mutu Perguruan Tinggi (PT). Calon mahasiswa mencari PT yang berkualitas dan mampu menjawab semua tantangan masa depan. Indikasi ini tercermin dari lulusan yang berdaya saing, mempunyai pengetahuan, dan kompetensi yang tinggi. Penilaian dan penentuan PT serta program studi apa yang akan dipilih oleh calon mahasiswa diibaratkan sebagai konsumen yang ingin membeli suatu barang atau produk. Sebelum calon mahasiswa menetapkan dan menentukan pilihan yang diminati pada sebuah program studi yang ada di sebuah PT tentunya banyak unsur dan faktor yang harus dipertimbangkan di antaranya faktor yang tergolong ke dalam 7P yaitu: product, price, place, promotion, people, physical evident, process, dan variabel-variabel lainnya (Wijaya, 2016).

IAIN Lhokseumawe adalah kampus yang membentuk mahasiswa dengan sekolah pendidikan Agama Islam dan merupakan satu-satunya yang ada di kota Lhokseumawe. Sejak perubahan alih status IAIN yang ditetapkan pada PEPRES No. 72 Tahun 2016 melahirkan 4 (empat) program studi, di antaranya pada Fakultas Syariah, yakni Program Studi Astronomi, Fakultas Ushuluddin dan Dakwah memiliki Program Studi Tafsir dan Hadits, sedangkan dua program studi lainnya ada di Fakultas Ekonomi dan 
Bisnis Islam (FEBI) yaitu Program studi Perbankan Syariah dan Akuntansi Syariah yang sekaligus menjadi paling tinggi peminatnya dibandingkan dengan program studi baru pada fakultas lain (iainlhokseumawe.ac.id, 2020). Data mahasiswa baru di program studi baru di IAIN Lhokseumawe dapat dilihat di Gambar 1.

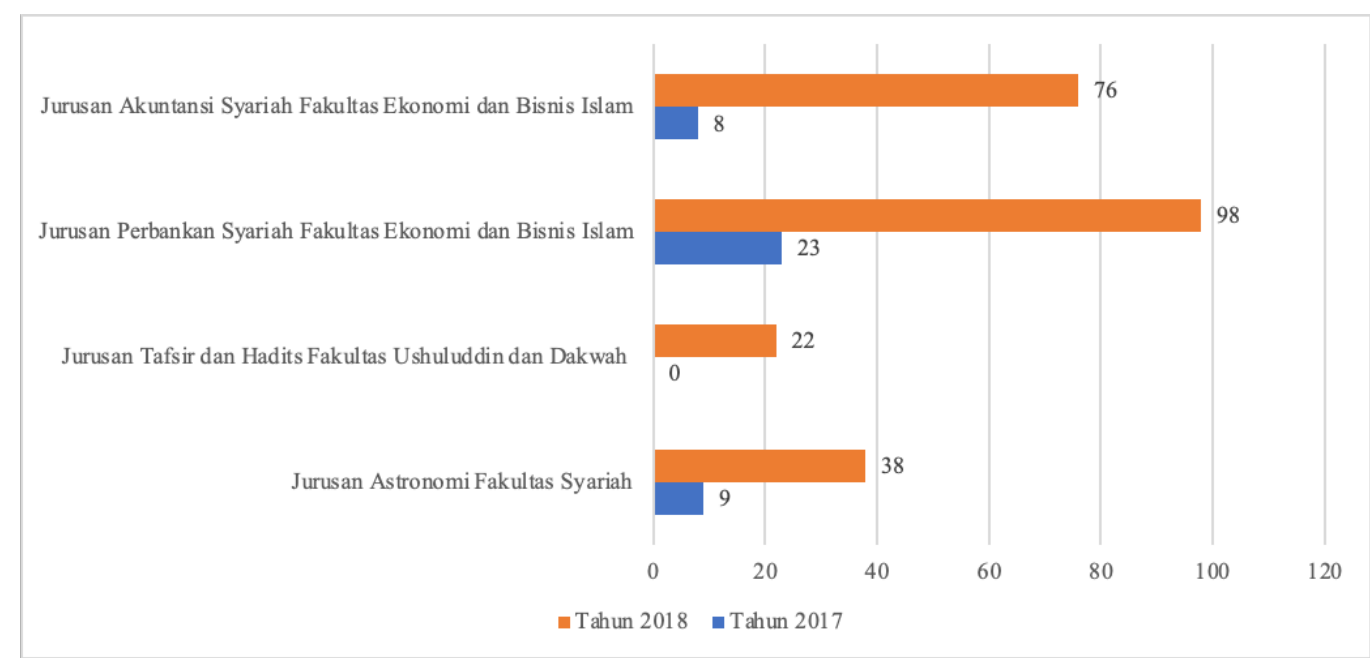

Sumber: IAIN Lhokseumawe (2019)

\section{Gambar 1. JUMLAH MAHASISWA BARU DI PROGRAM STUDI BARU DI IAIN LHOKSEUMAWE}

Dari Gambar 1, kenaikan jumlah mahasiswa dari tahun 2017 ke 2018 untuk Program studi Perbankan Syariah sebesar 426,1\% dan akuntansi syariah sebesar 937,5\%. Kenaikan kuantitas yang sangat signifikan pada kedua program studi baru tersebut mengindikasikan bahwa FEBI lebih diminati jika dibandingkan dengan fakultas-fakultas lain yang juga memiliki program studi baru di lingkungan IAIN Lhokseumawe.

Hasil survey awal menunjukkan mahasiswa dan calon mahasiswa memilih Program studi Perbankan Syariah dan Akuntansi Syariah karena kedua program studi tersebut mempunyai peluang dan kesempatan kerja yang cukup besar di dunia kerja. Hal ini diperkuat dengan penetapan pemberlakuan Qanun No. 11 Tahun 2018 tentang Lembaga Keuangan Syariah (LKS) yang menyatakan deklarasinya untuk seluruh lembaga keuangan (LK) yang beroperasi di Aceh maupun LK yang beroperasi di luar Aceh akan tetapi mempunyai kantor pusat di Aceh, baik itu lembaga perbankan maupun lembaga keuangan nonformal lainnya diwajibkan menjalankan, melaksanakan prinsip-prinsip syariah dan segala yang berlaku di dalamnya harus sesuai dengan ketentuan syariah Islam.

Ketentuan Qanun Aceh ini menjadi suatu terobosan penting bagi seluruh lapisan masyarakat untuk mempersiapkan diri dalam membangun ekonomi menuju sistem yang berbasis syariah artinya sesuai Qanun LKS, batas waktu yang ditetapkan bagi lembaga keuangan (LK) yang ada di wilayah Aceh paling lama tiga tahun sejak Qanun LKS terbentuk atau hingga Januari 2022 semua LK di Aceh sudah berprinsip syariat. Penegasan pemberlakuan peraturan Qanun menjadi peluang bagi mahasiswa program studi baru FEBI IAIN Lhokseumawe sebagai PT yang men-supply kebutuhan sumber daya manusia (SDM) yang memiliki kompetensi latar belakang pendidikan ekonomi syariah atau lulusan ekonomi Syariah (JDIH Aceh, 2019). Selain itu, dari hasil wawancara awal dengan stakeholder di bidang perbakan syariah, lulusan Akuntansi Syariah dan Perbankan Syariah khususnya yang berlatar belakang Ekonomi dan Bisnis Islam akan memiliki prospek dan peluang pekerjaan yang sangat besar, mengingat lulusan tersebut mampu menguasai prinsip-prinsip muamalah yang sesuai dengan aturan Syariah.

Sayangnya, Program Studi Perbankan Syariah dan Akuntansi Syariah IAIN Lhokseumawe belum terakreditasi dan belum memiliki lulusan. Lulusan yang baik menunjukan bahwa proses pendidikan di lembaga tersebut baik dan berkualitas begitu pula sebaliknya. Tinggi rendahnya kualitas lulusan, 
dapat diketahui dari kurikulum yang dijadikan acuan pembelajaran, kualitas dosen yang mengelola perkuliahan, kualitas fasilitas belajar, kualitas lingkungan belajar, (tenang, nyaman, asri, aman dan lain-lain), kualitas manajemen, kualitas masukan calon mahasiswa dan kepemimpinan (Furchan, 2004). Usaha peningkatan kualitas lulusan dilakukan berdasarkan standar mutu SPMPT (Sistem Penjamin Mutu Perguruan Tinggi) dan tujuan masa depan program studi pada sebuah PT. Salah satu yang perlu diperhatikan dalam meningkatkan mutu pendidikan adalah kualitas mahasiswa sebagai ukuran reputasi bagi PT atau baik buruknya suatu lembaga pendidikan (Yuniati \& Mukti, 2017; Singgih, Moses, \& Rahmayanti, 2008).

Status akreditasi dari PT dan program studi merupakan cerminan kinerja PT dan program studi yang bersangkutan yang menggambarkan mutu, relevansi, dan efisiensi dari sebuah institusi pendidikan. Akrditasi perguruan tinggi oleh BAN-PT (Badan Akreditasi Nasional Perguruan Tinggi) mempunyai peran yang vital lulusan melamar pekerjaan. Oleh karena itu, calon mahasiswa akan memperhatikan akreditasi perguruan tinggi yang diminatinya. Sehingga, PT dan program studi terus meningkatkan mutu dan daya saing lulusannya untuk dapat memperoleh dan mempertahankan status akreditasi tersebut (Yulianingsih, 2015)

Selain akreditasi dan mutu lulusan, variabel biaya pendidikan (Wulandini S, 2017) dan promosi (Iriyanto, 2013). Hasil penelitian sebelumnya menunjukkan bahwa harga dan keluarga menjadi faktor yang memengaruhi keputusan mahasiswa untuk memiih Program Studi sebagai tempat kuliah (Artini, 2014). IAIN Lhokseumawe menetapkan biaya pendidikan berkisar pada angka Rp.900.000,- dan merupakan biaya Uang Kuliah Tunggal (UKT) terendah di seluruh Perguruan Tinggi Keagamaan Islam Negeri (PTKIN) yang ada di Indonesia berdasarkan KMA No. 157 tahun 2017 tentang UKT pada Perguruan Tinggi Keagamaan Islam Negeri di Kementerian Agama Tahun Akademik 20172018. Hal ini menjadi sebuah keunggulan dalam hal kepemimpinan harga bagi IAIN Lhokseumawe (SK Rektor tentang UKT IAIN Lhokseumawe, 2020).

Namun, biaya pendidikan yang rendah saja tidak cukup tanpa adanya sosialisasi dan promosi (Irianto, 2013). Promosi bisa dijadikan sebagai sarana komunikasi dalam menyampaikan informasi kepada konsumen, baik mengenai harga, kualitas, dan semua jenis produk yang akan dipasarkan. Jika dilakukan dengan perencanaan yang cermat dan matang, promosi akan menjadi sukses sehingga promosi menjadi tepat sasaran dan dapat meningkatkan penjualan. Promosi yang dilakukan oleh lembaga PT untuk memperoleh sebanyak mungkin calon mahasiswa yang akan mendaftar. Peran promosi dalam mengembangkan lembaga PT di masa yang akan datang sangat besar dan promosi dapat memengaruhi dan merubah jumlah pendaftaran calon mahasiswa baru pada sebuah lembaga PT yang dipromosikan, selain itu PT yang dipromosikan akan terkenal di masyarakat, dan memperoleh keuntungan lainnya. Informasi dan pesan yang diberikan secara menarik untuk calon pendaftar mahasiswa baru secara berkesinambungan akan memengaruhi calon mahasiswa yang mendaftar tertarik untuk mendaftar (Pasaribu, 2008). Penelitian sebelumnya menunjukkan bahwa calon mahasiswa menentukan program studi tujuan untuk melanjutkan studinya dengan berdasar pada ketertarikan (daya tarik), rasa suka, kepercayaan (Iriyani, 2010), jalur dan jenjang pendidikan, gelar dan sebutan (Revandi \& Djan, 2005), biaya pendidikan dan beasiswa, ketersediaan ma'had (asrama), komunikasi pemasaran, dan teknologi informasi (Sulaiman, 2011).

Penelitian ini bertujuan memperoleh faktor-faktor apa saja yang memengaruhi keputusan mahasiswa dalam memilih program studi baru di Fakultas Ekonomi dan Bisnis Islam IAIN Lhokseumawe dan menganalisis faktor apa yang paling dominan memengaruhinya serta adakah perbedaan faktor yang memengaruhi mahasiswa dalam memilih Program Studi Perbankan Syariah dan Akuntansi Syariah.

\section{KAJIAN PUSTAKA}

Kajian penelitian oleh Razak (2008) tentang analisis proses penentuan dan pengambilan keputusan mahasiswa untuk memilih program studi menemukan hasil (1) unsur sosial budaya mendapat pengaruh yang positif lagi signifikan pada faktor pribadi, motivasi dan pengambilan keputusan, namun tidak signifikan terhadap variabel formasi sikap maupun unsur persepsi dan anggapan 
mahasiswa (2) variabel kelompok rujukan mempunyai pengaruh yang positif dan signifikan terhadap faktor pribadi, indikator motivasi, persepsi, variabel formasi sikap dan unsur-unsur dari pengambilan keputusan. (3) berbeda dengan indikator variabel pribadi, unsur ini hanya berpengaruh positif dan signifikan terhadap variabel motivasi, variabel persepsi, formasi sikap, namun tidak ditemukan hasil yang signifikan terhadap indikator pengambilan keputusan (4) selanjutnya pada faktor motivasi terdapat pengaruh positif dan signifikan terhadap unsur persepsi, formasi sikap dan pengambilan keputusan (5) dan terakhir yang dibahas adalah faktor Persepsi, di mana persepsi berpengaruh positif terhadap pengambilan keputusan, tetapi signifikan untuk indikator variabel formasi sikap.

Hasil penelitian Sia (2011) terhadap 512 mahasiswa menunjukkan faktor-faktor yang menentukan keputusan mahasiswa memilih program studi adalah biaya SPP, lokasi, rekan dan teman sejawat, sekolah asal, dan kunjungan kampus. Kemudian, penelitian Kusumawati (2010) menemukan bahwa biaya UKT, reputasi PT, prospek lapangan pekerjaan, keputusan orang tua dan kualitas dapat memengaruhi keputusan mahasiswa dan calon mahasiswa dalam memilih program studi.

Penelitian Wirya, Agni Alam (2009) menghasilkan bahwa reputasi Islam menjadi faktor yang utama dan penting dalam memilih Program Studi Ekonomi Syariah, diikuti faktor fasilitas lembaga, unsur keluarga dan variabel lingkungan, dan faktor biaya merupakan faktor-faktor selanjutnya. Hasil penelitian lain yang ditulis Padlee, Siti Falindah (2010) menemukan faktor utama dalam memilih program studi adalah fokus pelanggan dan fasilitas yang digunakan mahasiswa.

Menurut Wagner, Karl 2009) faktor utama yang mampu memengaruhi mahasiswa memilih program studi di sebuah PT adalah biaya pendidikan, isi dan struktur kurikulum, dan ada beberapa faktor lainnya yang menjadi bahan pertimbangan yaitu program khusus dari PT, pengaruh anggota keluarga, fasilitas PT atau lembaga, teman dan rekan sejawat serta sistem informasi lembaga. Jacqueline Liza Fernandez (2010) mengemukakan alasan utama pemilihan PT terletak pada prospek mendapatkan lapangan kerja, tempat menambah ilmu pengetahuan dan pengalaman, fasilitas mengakses internet, kualitas pendidikan yang diberikan dan biaya-biaya, reputasi yang baik juga menjadi salah satu faktornya serta memiliki hubungan bisnis yang kuat. Begitu juga senada dengan penelitian Samsinar Sidin, Hussin, \& Tan Ho Soon (2003) di mana mereka menemukan bahwa pemilihan universitas didasarkan pada kualitas akademik yang diperoleh, fasilitas kampus, lingkungan kampus yang kondusif, dan karakteristik pribadi.

Kemudian hasil penelitian Anas Al-Fattal (2010) mengungkapkan bahwa ada 5 tahapan yang harus dilalui dalam proses pemilihan PT di antaranya motivasi, kumpulan informasi, alternatif evaluasi, keputusan implementasi dan evaluasi pasca pemilihan. Selain itu masih ditemukan 5 elemen lainnya dari konsep marketing mix (MM) berupa teaching and learning, customer centred focus (CCF), finance, branding and environment.

Penelitian ini akan menganalisis variabel atau faktor yang terdiri dari: (1) Produk diinterpretasikan pada: program studi yang ditawarkan, kurikulum dan silabus, citra/image, status akreditasi, kualitas pendidikan, kegiatan kemahasiswaan, sistem pendidikan dan waktu penyelesaian; (2) Price (harga) diinterpretasikan berupa: biaya pendaftaran, biaya pendidikan (SPP), persyaratan pembayaran, potongan biaya pendidikan, biaya pendaftaran, biaya hidup, uang pembangunan, sumbangan lainnya dan ketersediaan beasiswa; (3) Place berupa: Lokasi kampus, transportasi umum, kota pendidikan dan keamanan lingkungan; (4) Physical Evident berupa kelengkapan fasilitas Program studi, kondisi lingkungan Program studi, kondisi gedung Program studi, perpustakaan, jumlah peralatan mengajar yang dimiliki, keadaan ruang kuliah, jumlah laboratorium yang dimiliki, fasilitas komputer, asrama ( $m a$ 'had), dan faslitas olah raga; (5) Promotion meliputi: keluarga, teman, guru, jumlah peminat, daya tampung program studi, kemudahan masuk prodi, kemudahan memperoleh pekerjaan, pengembangan potensi diri, prospek pekerjaan untuk suatu karir pekerjaan dimasa depan, peluang kerja yang diharapkan, gaji atau insentif yang diharapkan, status sosial yang diharapkan dan ketertarikan pada suatu pekerjaan; nama populer, brosur, baliho, media sosial, surat kabar; (6) People meliputi: tenaga pengajar (dosen), pimpinan PT dan Tenaga administrasi; (7) Proses meliputi orientasi spesialisasi, 
Ismaulina dkk. Studi Pemasaran Jasa Pendidikan: Faktor-Faktor yang Memengaruhi Mahasiswa Memilih Program Studi Baru

masa depan karir, kerjasama ekstenal, kesempatan magang, praktikum dan hubungan alumni; (8) Faktor ekonomi berupa penghasilan orang tua; (9) Faktor Issu Positif perubahan status dari STAIN Malikussaleh Lhokseumawe menjadi IAIN Lhokseumawe.

\section{METODE PENELITIAN}

Penelitian ini menggunakan metode kuantitatif. Populasi adalah mahasiswa Program Studi Perbankan Syariah dan Akuntansi Syariah di FEBI IAIN Lhokseumawe tahun 2017-2018. Jumlah populasi telah 204 orang mahasiswa dan jumlah sampel 67 mahasiswa. Penentuan unit sampel dihitung berdasarkan banyaknya persentase mahasiswa per program studi yang diteliti dan tahun dengan teknik proportional stratified random sampling (PSRS). Teknik analisis data yang digunakan dalam penelitian ini dengan analisis faktor variabel. Variabel Penelitiannya terdiri dari faktor-faktor dengan indikator 7P yakni variabel product, variabel price, variabel place, variabel promotion, variabel physical evident, variabel people dan variabel process) (Suryabrata, 2001) dan terdapat beberapa unsur lain yang terkait didalamnya seperti yang telah dipaparkan sebelumnya yaitu ditambah dengan indikator dari faktor ekonomi dan faktor isu positif yang dapat memengaruhi pengambilan keputusan responden dalam memilih jurusan pada sebuah PT (Wijaya, 2016). Perhitungan analisis variabel faktor menggunakan Program SPSS for Windows versi 22.

\section{HASIL DAN PEMBAHASAN}

\section{Hasil KMO and Bartlett's Test}

Uji KMO \& Bart lett's Test menunjukkan bahwa KMO MSA sebesar 0,779>0,50 dan nilai Bart lett's Test of Spheri city (Sig.) 0 (nul) $<0,05$, maka analisis faktor dalam penelitian ini dapat dilanjutkan mengingat semua persyaratan yang ditetapkan sudah dipenuhi.

\section{Hasil Uji Correlation Matrix}

Uji komunalitas dilakukan untuk menunjukkan apakah nilai setiap variabel yang akan diteliti mampu menjelaskan variabel faktor atau tidak. Masing-masing Variabel dianggap mampu menjelaskan variabel faktor apabila nilai ekstraksinya $>0,50$. Berdasarkan output komunalitas seperti yang terlihat pada tabel di atas, diketahui bahwa semua nilai Extraction-nya untuk masing-masing variabel faktor adalah lebih besar dari 0,50 sehingga sembilan variabel faktor yang diuji dapat dipakai sebagai unsur dalam menjelaskan faktor. Data selengkapnya dapat dilihat di Tabel 1.

\section{Tabel 1. HASIL UJI COMMUNALITIES}

\begin{tabular}{ccc}
\hline Variabel & Initial & Extraction \\
\hline Produk & 1,000 &, 549 \\
Harga & 1,000 &, 541 \\
Tempat & 1,000 &, 572 \\
Promosi & 1,000 &, 565 \\
Buktifisik & 1,000 &, 511 \\
Proses & 1,000 &, 547 \\
Ekonomi & 1,000 &, 936 \\
Isupositif & 1,000 &, 768 \\
Keputusan & 1,000 &, 935 \\
\hline
\end{tabular}

Sumber: Data diolah (2020)

\section{Hasil Uji Eigenvalue dan Faktor Loading}

Berdasarkan tabel 2, terdapat dua faktor yang dapat terbentuk dari 9 variabel yang dianalisis, di mana syarat untuk menjadi sebuah faktor, nilai Eigenvalues nya harus lebih besar dari satu. Nilai Eigenvalues Component 1 sebesar 3,554, maka menjadi faktor 1 dan mampu menjelaskan 39,379\% variasi, sedangkan nilai Eigenvalues Component 2 sebesar 1,070, maka menjadi faktor 2 dan mampu menjelaskan $11,890 \%$ variasi. 
Tabel 2. HASIL UJI EIGENVALUE

\begin{tabular}{ccccccc}
\hline & \multicolumn{3}{c}{ Initial Eigen values } & \multicolumn{5}{c}{ Extraction Sums of Squared Loadings } \\
Component & Total & \% of Varian ce & Cumulative \% & Total & \% of Variance & Cumulative \% \\
\hline 1 & 3,544 & 39,379 & 39,379 & 3,544 & 39,379 & 39,379 \\
2 & 1,070 & 11,890 & 51,268 & 1,070 & 11,890 & 51,268 \\
3 &, 965 & 10,727 & 61,995 & & & \\
4 &, 841 & 9,348 & 71,344 & & & \\
5 &, 765 & 8,503 & 79,846 & & & \\
6 &, 660 & 7,333 & 87,179 & & & \\
7 &, 476 & 5,294 & 92,473 & & & \\
8 &, 384 & 4,262 & 96,734 & & & \\
9 &, 294 & 3,266 & 100,000 & & & \\
\hline
\end{tabular}

Sumber: Data diolah (2020)

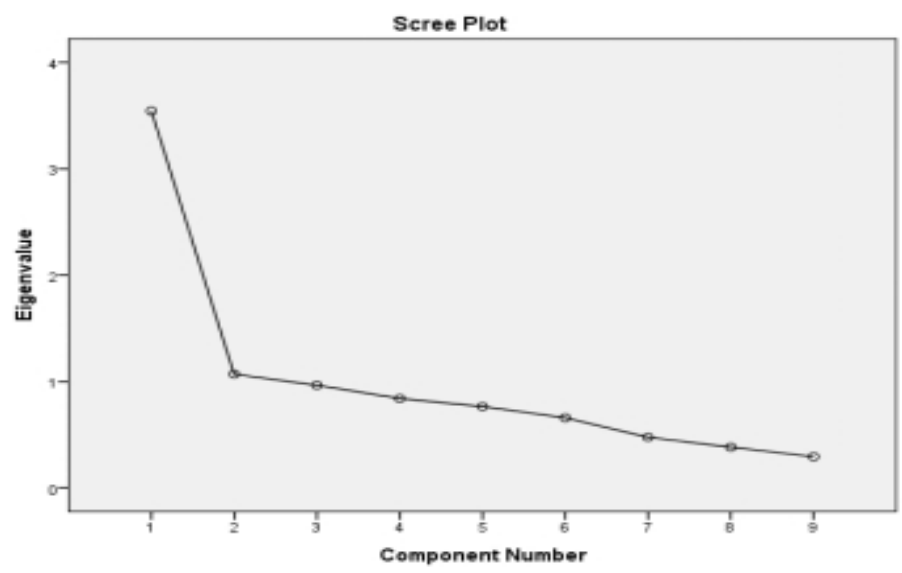

Sumber: Data diolah (2020)

Gambar 2. SCREE PLOT

Gambar 2 menunjukkan Scree Plot dilihat dari jumlah faktor yang terbentuk melalui titik-titik komponen yang memiliki nilai Eigen value $>1$. Pada Gambar 2, terlihat ada dua titik komponen yang mempunyai nilai Eigen value $>1$. Artinya, ada dua faktor yang dapat terbentuk di dalamnya. Selanjutnya, alternatif prefesensi digunakan agar dapat mengetahui pilihan variabel mana saja yang termasuk ke dalam faktor 1 dan variabel apa saja yang termasuk ke dalam golongan faktor 2 . Untuk itu, dilakukan uji independent sample t-test.

\section{Hasil Uji Independent Sample T-test}

Berdasarkan Tabel 3, nilai sig. 2- tailed $(0,345)$ dan $(0,652)>0,05$. Artinya, tidak ada perbedaan antara variabel faktor pertama dan variabel faktor kedua yang memengaruhi keputusan mahasiswa dalam memilih program studi baru.

\section{Pembahasan}

Nilai komponen tertinggi ialah terdapat pada variabel faktor isu positif. Hal tersebut menunjukkan variabel faktor isu positif merupakan faktor yang lebih dominan dalam memengaruhi keputusan yang diambil oleh mahasiswa untuk memilih program studi baru di FEBI IAIN Lhokseumawe. Ini menggambarkan bahwa citra dan nama baik IAIN Lhokseumawe di masyarakat Kota Lhokseumawe dan sekitarnya memiliki reputasi yang sangat bagus di mana didukung oleh dosen-dosennya yang merupakan alumni pasantren baik tradisional maupun modern.

Lokasi kampus yang sangat strategis juga menjadi faktor yang dapat memengaruhi bagi mahasiswa dalam menentukan pilihan. Di samping itu, keadaan dan kondisi ruang kuliah juga menjadi bahan pertimbangan bagi mahasiswa dalam menentukan keputusannya memilih tempat belajar. 
Ismaulina dkk. Studi Pemasaran Jasa Pendidikan: Faktor-Faktor yang Memengaruhi Mahasiswa Memilih Program Studi Baru

Tabel 3. UJI INDEPENDENT SAMPLE T-TEST

\begin{tabular}{|c|c|c|c|c|c|c|c|c|c|c|}
\hline & & $\begin{array}{r}\text { Leve } \\
\text { Test } \\
\text { Equali } \\
\text { Varia }\end{array}$ & $\begin{array}{l}\text { ne's } \\
\text { for } \\
\text { ty of } \\
\text { nces }\end{array}$ & & & t- tes & for Equality & $y$ of Means & & \\
\hline & & & & & & Sig. (2- & Mean Dif & $\begin{array}{l}\text { Std. Error } \\
\text { Differenc }\end{array}$ & $\begin{array}{r}95 \% \text { Conf } \\
\text { Interval of } \\
\text { feren }\end{array}$ & $\begin{array}{l}\text { i dence } \\
\text { the Dif } \\
\text { ce }\end{array}$ \\
\hline & & $\mathrm{F}$ & Sig. & $\mathrm{t}$ & $\mathrm{df}$ & tailed) & ference & $\mathrm{e}$ & Lower & Upper \\
\hline Faktor1 & $\begin{array}{ll}\text { Equal variances } \\
\text { assumed }\end{array}$ & 6,987 & ,033 & $-1,013$ & 7 & ,345 &,- 082929 & ,081852 &,- 276477 & ,110620 \\
\hline & $\begin{array}{l}\text { Equal variances not } \\
\text { assumed }\end{array}$ & & &,- 594 & 1,093 & ,652 &,- 082929 & ,139578 & $-1,536985$ & 1,371128 \\
\hline
\end{tabular}

Sumber: Data diolah (2020)

Kemudian, faktor proses juga menjadi pengaruh pada mahasiswa dalam menentukan keputusan memilih program studi baru di FEBI IAIN Lhokseumawe. Hal tersebut dapat dianalisa melalui realita yang diinginkan oleh mahasiswa. Mahasiswa pada era ini yang semakin maju tidak hanya ingin mendapatkan teori-teori saja namun juga membutuhkan berbagai praktikum atau kerja lapangan di dalam merealisasikan ilmu-ilmu yang telah mereka peroleh di bangku kuliah, serta ingin menilai seberapa jauh mahasiswa tersebut mampu diserap sebagai tenaga kerja pada suatu instansi.

Faktor yang memengaruhi lainnya ialah bukti fisik, di mana sarana dan prasarana merupakan hal yang sangat penting dan dibutuhkan dalam membantu atau menunjang proses belajar mengajar, sehingga adanya sarana dan prasarana yang lengkap yang disediakan oleh program studi memberikan kenyamanan pada mahasiswa disaat mereka mengikuti proses perkuliahan, sehingga proses perkuliahannya pun berjalan dengan semakin lancar.

Faktor berikutnya terkait faktor harga serta ekonomi. UKT yang sangat murah membuat daya tarik tersendiri bagi calon mahasiswa dan keluarganya. Kondisi masyarakat kota Lhokseumawe di mana sering kita dapatkan keluarga yang tergolong kelas ekonomi rendah namun ingin anak-anaknya terus melanjutkan pendidikannya, dengan membayar uang kuliah yang murah namun mendapatkan fasilitas belajar yang mewah merupakan hal yang sangat penting bagi seluruh mahasiswa dan keluarganya.

Adapun faktor lain yang juga memengaruhi mahasiswa dalam menentukan keputusannya untuk memilih program studi baru di FEBI IAIN Lhokseumawe ialah faktor Produk. Program Studi Perbankan Syariah dan Program Studi Akuntansi Syariah merupakan program studi yang memiliki prospek dan peluang pekerjaan yang sangat besar. Lapangan kerja merupakan faktor terpenting yang juga menjadi pertimbangan oleh mahasiswa dalam memilih suatu program studi. Pertimbangan mereka jatuh pada apakah nanti setelah lulus mereka akan mampu mengikuti persaingan di dalam memasuki dunia kerja dan untuk memenangkan persaingan tersebut tentunya mereka harus mempunyai pengetahuan, keterampilan, dan etos kerja yang tinggi di bidang yang mereka pelajari.

Selain itu, disahkannya Qanun Aceh No. 11 Tahun 2018 tentang Lembaga Keuangan Syariah yang menyatakan segala lembaga keuangan yang beroperasi di Aceh maupun lembaga keuangan yang beroperasi di luar Aceh akan tetapi mempunyai kantor pusat di Aceh, baik itu lembaga perbankan maupun lembaga keuangan non formal lainnya diwajibkan melaksanakan prinsip-prinsipnya dan segala yang berlaku di dalamnya harus sesuai dengan syariah Islam.

Disahkannya Qanun D.I. Aceh No. 11 Tahun 2018 tentang Lembaga Keuangan Syariah menjadi suatu terobasan penting bagi mahasiswa. Kehadiran peraturan Qanun tersebut menjadi energi baru yang IAIN Lhokseumawe untk menciptakan dan menyediakan kebutuhan SDM yang berkompetensi dan menguasai ilmu kesyariahan. 
Faktor promosi melalui mengenalkan secara lebih luas akan keberadaan program studi-program studi baru pada FEBI IAIN Lhokseumawe yang dikemas dengan kreatif, menarik, dan komprehensif yang kemudian dibagikan melalui situs online, media internet serta berbagai media sosial. Kegaitan promosi atau penyebaran informasi secara masif tersebut dapat membuat calon mahasiswa dapat mengenal dan mengetahui keberadaan program studi-program studi baru pada FEBI IAIN Lhokseumawe.

Terakhir adalah faktor keputusan. Kecenderungan memilih program studi berdasarkan keputusan merupakan suatu hal yang mutlak akan dilakukan oleh calon mahasiswa tanpa dipengaruhi oleh suatu apapun. Pemilihan program studi baru pada FEBI IAIN Lhokseumawe telah menjadi keinginan atau tekad yang ada pada diri calon mahasiswa. Hal-hal yang menguatkan keputusan tersebut adalah minat atau kesukaan dan didukung oleh faktor-faktor lainnya seperti isu positif, promosi, dukungan orang tua, harga, ekonomi, harga, dan tempat.

\section{KESIMPULAN}

Berdasarkan hasil analisis faktor, maka terdapat Sembilan macam faktor yang memengaruhi keputusan setiap mahasiswa dalam memilih program studi baru yang ada di FEBI IAIN Lhokseumawe. Adapun 9 faktor tersebut terbagi ke dalam dua kelompok, yaitu: faktor pertama terdiri dari tempat, proses, bukti fisik, harga, produk, keputusan, dan ekonomi sedangkan faktor kedua terdiri dari isu positif dan promosi. Faktor yang paling dominan memengaruhi setiap keputusan mahasiswa dalam memilih program studi baru yang ada di lingkungan FEBI IAIN Lhokseumawe adalah isu positif, disusul oleh faktor tempat, proses, bukti fisik, harga, produk, promosi, keputusan, dan ekonomi. Hasil penelitian menunjukkan bahwa tidak ada perbedaan antara variabel Faktor pertama dan variabel Faktor kedua dalam memengaruhi keputusan memilih mahasiswa di setiap program studi baru yang ada pada FEBI (Fakultas Ekonomi dan Bisnis Islam). Penelitian terbatas hanya pada prodi yang memiliki jumlah peminat terbanyak di satu institusi perguruan tinggi agama Islam saja. Penelitian selanjutnya dapat melibatkan orang tua mahasiswa serta membandingkan dengan program studi lain dengan didukung metode penelitian lainnya untuk mendapat gambaran yang lebih utuh untuk mempelajari faktor-Faktor yang memengaruhi mahasiswa memilih program studi baru.

\section{ACKNOWLEDGMENT}

Artikel ini merupakan publikasi penelitian yang didanai dengan Hibah Penelitian Pengembangan Program Studi tahun 2019 oleh Kementerian Agama Republik Indonesia dan Lembaga Penelitian dan Pengabdian Masyarakat IAIN Lhokseumawe.

\section{DAFTAR PUSTAKA}

Al-Fattal, Anas (2010). Understanding Student Choice of University and Marketing Strategies in Syrian Private Higher Education. Doctor of Philosophy: University of Leeds.

Fernandez, Jacqueline Liza (2010). An Explanatory Study of Factors Influencing the Decision of Students to Study at Universiti Sains Malaysia. Kajian Malaysia. Vol. 28. No. 2.

Furchan, Arief (2004). Transformasi Pendidikan Islam di Indonesia. Yogyakarta: Gama Media.

IAIN Lhokseumawe (2019). Data Akademik IAIN Lhokseumawe. Data Internal IAIN Lhokseumawe: Tidak Dipublikasikan

iainlhokseumawe.ac.id (2020). Sekilas Tentang Sejarah IAIN Lhokseumawe. Retrieved 31 Desember 2020 from https://www.iainlhokseumawe.ac.id/sejarah-iain-lhokseumawe/ 
Ismaulina dkk. Studi Pemasaran Jasa Pendidikan: Faktor-Faktor yang Memengaruhi Mahasiswa Memilih Program Studi Baru

Iriyani, Yani. (2010). Analisis Faktor-faktor yang Memengaruhi Minat Studi Mahasiswa dalam Menempuh Pendidikan di Universitas Widyatama. Prosiding Seminar Nasional IV Manajemen \& Rekayasa Kualitas 2010, Bandung.

Iriyanto, Setia (2013). Pengaruh Biaya Promosi terhadap Jumlah Mahasiswa Baru Analisis Promosi Mix di Universitas Muhammadiyah Semarang. http://jurnal.unimus.ac.id, diakses pada 17 maret 2019).

JDIH Aceh (2019). Qanun Lembaga Keuangan Syariah untuk Memajukan Ekonomi Aceh. Retreived 31 Desember 2020 from https://jdih.acehprov.go.id/news/post/qanun-lembaga-keuangansyariah-untuk-memajukan-ekonomi-aceh

Keputusan Menteri Agama Republik Indonesia Nomor 157 Tahun 2017 tentang Uang Kuliah Tunggal pada Perguruan Tinggi Keagamaan Negeri di Kementerian Agama Tahun Akademik 20172018. 8 Maret 2017

Kusumawati, Andriani (2010), Privatization and Markrtization of Indonesian Publik University: a Systematic Review of Student Choice Criteria Literature. Research Online Sydney Business School - Papers Mahasiswa. Html.

Sidin, Samsinar Md, Siti Rahayu Hussin \& Tan Ho Soon (2003), An Exploratory Study of Faktor Influencing the College Choice Decision of Undergraduate Student in Malaysia. Asia Pacific Management Review, 8(3). 259-280

Sia, Yoseph Kee Ming (2011). Post Secondary Student' Behavior in the College Choice Decision. Journal of Marketing Research \& Case Studies. DOI: 10.5171/2011.440964

Padlee, Siti Falindah, Abdul Razak Kamaruddin, \& Rohaizat Baharun (2010). Internasional Studens' Choice Behavior for Higher Education at Malaysian Private Universities. International Journal of Markrting Studies. 2(2). 202-211.

Pasaribu, B. 2008. Faktor Daya Tarik FKIP UIKA Bogor dalam Persepsi Mahasiswa, Laporan Penelitian Internal FKIP UIKA Bogor.

Qanun Aceh Nomor 11 Tahun 2018 tentang Lembaga Keuangan Syari’ah. Provisi Daerah Istimewa Aceh. 31 Desember 2018

Razak, Mashur (2008). Analisis Proses Pemgambilan Keputusan Mahasiswa dalam Memilih Program Studi pada PTS di Sulawesi Selatan. Social and Culture, Reference Group: Marketing Communicatin. Vol 5. No. 2 hal. 89-102.

Singgih, Moses L \& Rahmayanti. 2008. Faktor-faktor yang mempengaruhi kualitas pendidikan

SK Rektor tentang UKT IAIN Lhokseumawe Nomor 390 Tahun 2020. 27 Juli 2020. https://www.iainlhokseumawe.ac.id/sk-rektor-tentang-ukt-iain-lhokseumawe/

Supranto. J (2004) Analisis Multivariat Arti dan Interprestasi. Jakarta: Rineka Cipta.

Suryabrata, Sumadi (2001). Psikologi Kepribadian. Jakarta: PT. Raja Grafindo Persada.

Wagner, K. \& Fard, P.Y (2009) Faktor Influencing Malaysian Students' Intention to Study at a Higher Educational Institution. Chinese American Sholars Association: New York, New York, USA. Retrieved 11 Juli 2009 from http://www.gcasa.com/PDF/malahsia/Wagner-Fard.pdf.

Wijaya, David (2016). Pemasaran Jasa Pendidikan. Jakarta: Salemba Empat. 
Wirya, Agni Alam \& Indah Piliyanti (2009). Penggunaan Analisis Faktor Untuk Menentukan Kriteria Pemilihan Program Studi Ekonomi Islam. Jurnal EKBISI. 4(1). 85-97.

Yulianingsih, Yuyun (2015). Manajemen Akreditasi Program Studi Pada Perguruan Tinggi. AlIdarah Jurnal Kependidikan Islam, Vol.5 No. 1 Hal 92-116.

Yuniati, Rosita dan Patria Mukti (2017). Analisis 4P (Product, Price, Place dan Promotion) dalam Pengambilan Keputusan Calon Mahasisea memilih Perguruan Tinggi, Jurnal Psikologi Perseptual, 2(1). 1-8. https://doi.org/10.24176/perseptual.v2i1.2217 